\title{
Modern Machinaries for Processing Organic Foods in Developed Cities
}

\author{
S. Janifarvinnarasi, M.M. Shanmugapriya, C. Archanapriya
}

\begin{abstract}
A five phases applied system was proposed for breaking down customer buy basic leadership towards natural nourishment in urban China. The five phases are impacting stage, psychological/full of feeling stage, assessment of choices organize, conduct aims stage and buy arrange. The accentuation was set on the affecting angles and measurements of this procedure in the Chinese setting. The four develops - specifically, item, administrative, way of life and ethnocentrism - were situated in the impacting stage. The examination configuration is prevalently quantitative in nature. The information was gathered in China in two phases. Stage one included 204 substantial online studies which were gathered with the end goal of the pilot study. Stage two, the principle study, included 964 paper-based reviews which were gathered in four significant urban areas. The information investigations were performed utilizing exploratory factor examination, corroborative factor investigation and basic condition displaying.
\end{abstract}

Key words: New food technology, growing health awareness, busier lifestyle and global environmental

\section{INTRODUCTION}

Purchasers have begun to address what they eat and the nourishment creation forms, just as question whether nourishment is sheltered (IFOAM 2012). Natural nourishment has created as one of the quickest developing regions of the world nourishment advertise. From being a specialty advertise, organics have advanced as standard items. Natural nourishment studies have drawn the consideration of researchers and government strategy creators, and numerous studies have been attempted in created nations. In some creating markets, for example, China, because of its emotional and later financial improvement, a progression of nourishment embarrassments have harmed the nourishment business and trust in certain parts of the business (Euromonitor International 2010). This thusly has brought issues to light and affectability towards natural nourishment items. China's monetary advancement has made an enormous white collar class receptive to western patterns and way of life adjustment. Organics have developed as a significant division of nourishment and, while

Revised Manuscript Received on December 30, 2019.

S. Janifarvinnarasi, Assistant Professor, Department of Science \& Humanities,Bharath Institution Of Higher Education And Research TamilNadu,India.Email: mjjaa24@gmail.com

M.M. Shanmugapriya, Assistant Professor, Department of Science \& Humanities,Bharath Institution Of Higher Education And Research TamilNadu,India.Email: priyashammu@ gmail.com

C. Archanapriya Assistant Professor, Department of Science \& Humanities,Bharath Institution Of Higher Education And Research TamilNadu,India.Email: Archanapriya854@gmail.com dominatingly comprehended and expended in western nations, it is moderately new in nations, for example, China (Yin et al. 2010). It is clear from this

exploration that couple of concentrates identified with Chinese customers purchasing natural nourishment have been done. [1]-[4]

The essential target of this examination is to explore the determinants of shopper buy conduct identifying with natural nourishment in urban communities of territory China. China, the land focal point of this investigation, has encountered sensational financial development over the most recent 20 years. Its natural nourishment part has become quicker than the overall normal (IFOAM 2006) and the market has been creating at a yearly twofold digit rate over the previous decade (US Department of Agriculture 2008). Authority figures for the careful offers of natural nourishment items are inaccessible, despite the fact that they had an expected market estimation of US\$1.1 billion out of 2008 (International Trade Center 2011). As per one source, China was the fourth biggest natural market on the planet (Zhou 2008b). It is building up a prosperous urban white collar class and furthermore an ostracize network who are keen on acquiring natural nourishment (Euromonitor International 2008b). Enormous global retailers, for example, Wal-Mart (US) and Carrefour (France) have altogether expanded their offers of natural nourishment items in China, despite the fact that these are generally increasingly costly for buyers (Baer 2007; Sanders 2006). [4]-[7]

\section{RESULTS \& DISCUSSION}

The investigation by Furst et al. (1996) distinguishes worth factors in the nourishment decision process, including tactile discernments, fiscal contemplations, wellbeing and sustenance, overseeing connections and quality. So also, Lennernas et al. (1997) propose that taste, wellbeing, long timeframe of realistic usability, quality or freshness, value, family inclination and propensities are the most significant elements which effect the decision of nourishment. These investigations agree with a natural nourishment study by Wier and Calverley (2002) in inspiring individual client esteems, for example, items' medical advantages, taste and freshness, which are a higher priority than open qualities, for example, ecological and creature welfare. [8]-[10]

Hansen (2001) found numerous similitudes in the intentions of Chinese and Western purchasers in regards to the buy choice conduct of fish, with the most significant components being high item quality, providers' unwavering quality and administration level, item 


\section{Modern Machinaries for Processing Organic Foods in Developed Cities}

accessibility, item affirmation by an authorized organisation and aggressive costs.

Likewise, de Magistris\&Gracia (2008) researched the buyer choice procedure of naturally created nourishment items. It discovered customers' frames of mind towards wellbeing characteristics, for example, sound eating regimen and adjusted way of life, and towards the earth are the most significant variables which clarify purchasers' basic leadership forms for natural nourishment items for Italian buyers. Despite what might be expected,

Padel and Foster (2005), in their UK study, underline that the decisionmaking procedure about natural nourishment is mind boggling, and the significance of inspirations and boundaries may vary between classifications. They exhibit a need to separate different motivations to purchase natural nourishment as per item classes, and give bits of knowledge into exchange offs that shoppers make among contending and clashing qualities and necessities.

Limitation of the studies

Purchasers have begun to address what they eat and the nourishment creation forms, just as question whether nourishment is sheltered (IFOAM 2012). Natural nourishment has created as one of the quickest developing regions of the world nourishment advertise. From being a specialty advertise, organics have advanced as standard items. Natural nourishment studies have drawn the consideration of researchers and government strategy creators, and numerous studies have been attempted in created nations. In some creating markets, for example, China, because of its emotional and later financial improvement, a progression of nourishment embarrassments have harmed the nourishment business and trust in certain parts of the business (Euromonitor International 2010). This thusly has brought issues to light and affectability towards natural nourishment items. China's monetary advancement has made an enormous white collar class receptive to western patterns and way of life adjustment. Organics have developed as a significant division of nourishment and, while dominatingly comprehended and expended in western nations, it is moderately new in nations, for example, China (Yin et al. 2010). It is clear from this exploration that couple of concentrates identified with Chinese customers purchasing natural nourishment have been done. [11]-[16]

The essential target of this examination is to explore the determinants of shopper buy conduct identifying with natural nourishment in urban communities of territory China. China, the land focal point of this investigation, has encountered sensational financial development over the most recent 20 years. Its natural nourishment part has become quicker than the overall normal (IFOAM 2006) and the market has been creating at a yearly twofold digit rate over the previous decade (US Department of Agriculture 2008). Authority figures for the careful offers of natural nourishment items are inaccessible, despite the fact that they had an expected market estimation of US\$1.1 billion out of 2008 (International Trade Center 2011). As per one source, China was the fourth biggest natural market on the planet (Zhou 2008b). It is building up a prosperous urban white collar class and furthermore an ostracize network who are keen on acquiring natural nourishment (Euromonitor International 2008b). Enormous global retailers, for example, Wal-Mart (US) and Carrefour (France) have altogether expanded their offers of natural nourishment items in China, despite the fact that these are generally increasingly costly for buyers (Baer 2007; Sanders 2006). [17]-[20]

\section{CONCLUSION}

A five phases applied structure was proposed to explore purchaser basic leadership towards natural nourishment in urban China. This system was supported in three models: CDP, Hierarchy of Effects and TPB. The five phases of the reasonable system were impacting, psychological/emotional, assessment of options, conduct goals and buy. The accentuation was put on the affecting viewpoints and measurements of this procedure in the Chinese setting. The four builds, to be specific item, administrative, way of life and ethnocentrism, were operationalised in the affecting stage. This is the main investigation of its sort in the natural nourishment utilization explore, which has coordinated three understood models to research shopper purchaser conduct. The discoveries of this examination have uncovered that Chinese customers' frames of mind towards natural nourishment are impacted by the components of item, administrative and in part way of life (assortment chasing and extravagance). [21]-[24]

Also it was uncovered that every one of the measurements and their segments referenced above essentially affected the social aims for the acquisition of natural nourishment in urban China through the interceding impacts of shoppers' demeanors and their pre-buy assessment. The impact of statistic and division factors was likewise inspected. Chinese urban purchasers currently add to being one of the biggest buyer showcases on the planet. Examining their purchasing conduct is basic for understanding the general Chinese shopper profile. Results got by the last best-fit model have shown that Structural Equation Modeling is a solid factual method to address different issues related with the buy conduct of natural nourishment items. This model has the ability to at the same time look at different elements and their interrelationships which impact purchaser basic leadership towards the acquisition of natural nourishment. The hypothetical and handy business suggestions altogether added to a further comprehension of urban Chinese customers' buy conduct of natural nourishment items. This examination has tried to add to this comprehension.

\section{REFERENCES}

1. Vasanthi, S. \& Rabiyathul Basariya, S. 2019, "Influence of value analysis and cross training in industry", International Journal of Engineering and Advanced Technology, vol. 8, no. 6, pp. 1810-1811.

2. Velvizhi, R., Sri Gowtham, S. \& Jeya Priya, D. 2019, "Examination of early feedbacks for effective product retailing on E-commerce websites", International Journal of Engineering and Advanced Technology, vol. 8, no. 6 Special Issue 2, pp. 703-706.

3. Anuradha, C., Pothumani, S. \& Kavitha, R. 2019, "A novel method towards E-commerce", International 
Journal of Engineering and Advanced Technology, vol. 8, no. 6 Special Issue 2, pp. 535-538.

4. Thomas, J. \& Rabiyathul Basariya, S. 2019, "A study on the issues of financial ratio analysis", Indian Journal of Public Health Research and Development, vol. 10, no. 3, pp. 1079-1081.

5. Ramachandran, S. \& Rabiyathul Basariya, S. 2019, "Online marketing - study on customer satisfaction and relationship", Indian Journal of Public Health Research and Development, vol. 10, no. 3, pp. 1072-1078.

6. Priya, R., Vinothini, G. \& Cor Jesu, C.D. 2019, "The mentor-protégé relationship for professional growth", Journal of Advanced Research in Dynamical and Control Systems, vol. 11, no. 9 Special Issue, pp. 1110-1119.

7. Jannifer Rani, N., Bina Pani, S. \& Nimisha, N.S. 2019, "A study on money back polices available in LIC", Journal of Advanced Research in Dynamical and Control Systems, vol. 11, no. 9 Special Issue, pp 833-839.

8. Saillaja, V., Jhansi Rani, K. \& Catherine, R. 2019, "Global marketing management planning and organization", Journal of Advanced Research in Dynamical and Control Systems, vol. 11, no. 9 Special Issue, pp. 489-493.

9. Saillaja, V., Jhansi Rani, K. \& Catherine, R. 2019, "The new phase of marketing information system", Journal of Advanced Research in Dynamical and Control Systems, vol. 11, no. 9 Special Issue, pp. 482-488.

10. Thoufiqulla \& Raju, D.V. 2019, "Perception of indian investor towards investment in mutual funds with special reference to mip funds", Journal of Advanced Research in Dynamical and Control Systems, vol. 11, no. 5, pp. 177-183.

11. Jasmine, K.R.M. \& Basariya, S.R. 2018, "A study on the customers benefits on mutual funds", International Journal of Civil Engineering and Technology, vol. 9, no. 4, pp. 45-48.

12. Vasanthi, S. \& Basariya, S.R. 2019, "Pros and cons of on the job training versus off the job training", International Journal of Scientific and Technology Research, vol. 8, no. 10, pp. 671-674.

13. Pavithra, J. \& Ganesan, M. 2016, "A study on awareness and impact of micro-financial schemes", International Journal of Applied Business and Economic Research, vol. 14, no. 8, pp. 5449-5460.

14. Pavithra, J., Dilli Babu, P. \& Ambuli, T.V. 2014, "A study on budgetary control at Maruti Service Masters, Chennai", International Journal of Applied Business and Economic Research, vol. 12, no. 2, pp. 151-161.

15. Gunaraja, T.M. \& Venkatrama Raju, D. 2018, "Determining factors of organisational climate with reference to leadership styles", International Journal of Mechanical Engineering and Technology, vol. 9, no. 9, pp. 1327-1332.

16. Gunaraja, T.M. \& Venkatrama Raju, D. 2018, "The role of job satisfaction and training of employees in determining organisational climate of a selected industry", International Journal of Civil Engineering and Technology, vol. 9, no. 8, pp. 1266-1269.

17. Aarathy, T.S. \& Raju, D.V. 2018, "Performance appraisal and its effects on employees with respect to it sector in Chennai city", International Journal of Civil Engineering and Technology, vol. 9, no. 6, pp. 1535-1538.

18. Aarathy, T.S. \& Raju, D.V. 2018, "Employee perception towards performance appraisal system in IT sector", International Journal of Mechanical Engineering and Technology, vol. 9, no. 5, pp. 131-135.

19. Porselvi, W., Jublee, D. \& Sivanesan, G. 2018, "A study on factors influencing adoption of technology and innovation in banking industry, tamilnadu, India", International Journal of Mechanical Engineering and Technology, vol. 9, no. 5, pp. 789-800.

20. Akessa, G.M. and Dhufera, A.G., 2015. Factors That Influences Students Academic Performance: A Case of Rift Valley University, Jimma, Ethiopia. Journal of Education and Practice, 6(22), pp.55-63.

21. Miller, G. and Shih, C.C., 1999. A faculty assessment of the academic rigor of on-and off-campus courses in agriculture. Journal of Agricultural Education, 40, pp.57-65.

22. Tsinidou, M., Gerogiannis, V. and Fitsilis, P., 2010. Evaluation of the factors that determine quality in higher education: an empirical study. Quality Assurance in education, 18(3), pp.227-244.

23. Farooq, M.S., Chaudhry, A.H., Shafiq, M. and Berhanu, G., 2011. Factors affecting students' quality of academic performance: a case of secondary school level. Journal of quality and technology management, 7(2), pp.1-14.

24. Fitsilis, P., Gerogiannis, V. and Anthopoulos, L., 2014. Ontologies for software project management: a review. Journal of Software Engineering and Applications, 7(13), p.1096.
25. Adams, J.D. and Jaffe, A.B., 1996. Bounding the effects of $R \& D$ : an investigation using matched establishment-firm data(No. w5544). National bureau of economic research.

\section{AUTHORS PROFILE}

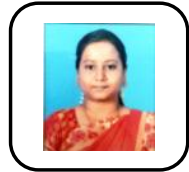

S. Janifarvinnarasi Assistant Professor, Department of Science \& Humanities,Bharath Institution Of Higher Education And Research TamilNadu,India

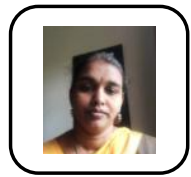

M.M. Shanmugapriya, Assistant Professor, Department of Science \& Humanities, Bharath Institution Of Higher Education And Research TamilNadu,India

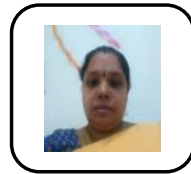

C. Archanapriya Assistant Professor, Department of Science \& Humanities,Bharath Institution Of Higher Education And Research TamilNadu 